\title{
The Comprehension of the Concept of Fath (Conquest) In the Light of Fath Al-Makkah
}

\author{
Assist. Prof. Dr. Mustafa Selim Yılmaz \\ Faculty of Theology \\ Karabuk University, Balıklar Kayası Campus \\ 78050 - Karabuk / TURKEY \\ msyilmaz@karabuk.edu.tr \\ s.mutekellim@gmail.com
}

\begin{abstract}
Is lam is the unique religion that calls itself peace. It also creates its concepts based on this name. Ironically, some various intellectual, religious and political groups are struggling to misinterpret Islam, which has such a deep-rooted peaceful background, and its concepts like jihad and fath (conquest) as it is the religion of war and point it out to be violent in every way in the global public opinion. In this article, it is tried to evaluate the concept of fath with the example of the Conquest of Makkah and interpret it faithful to its original. This example is peculiarly preferred because of that it is the beginning and the model of Islamic conquests. Furthemore, the main goal is frankly to protect human dignity in this example.
\end{abstract}

\section{Keywords:}

Fath (conquest), Islam, Fath Al Makkah, Human Dignity, Muhammad

\section{Council for Innovative Research}

Peer Review Research Publishing System

\section{Journal: Journal of Social Sciences Research}

Vol. 4, No. 1

jssreditor.cir@gmail.com

www.jssronline.com 


\section{ISSN 2321-1091}

\section{Introduction}

The word of "fath", which is the infinitive of the verb " $f-t-h$ ", stands for opening on the contrary of closing, ${ }^{1}$ reconcilement between adversaries, treasure ${ }^{2}$ and early rain. ${ }^{3}$ As a tem, it is basically understood to mean capture of non-Muslim lands and asking for help. ${ }^{4}$ Additionally, in Islamic teminology this term means that Allah give the Messenger Muhammad victory over the enemies in Makkah without fight so as to make Islam the most obvious to be understood on the basis of the Treaty of Hudaybiyah. ${ }^{5}$ There is one of the names of Allah derived from fath: "Fattah". It means that Allah opens so widely the gates of mercy, pray and sustenance to all mankind. ${ }^{6}$

The Messenger of Allah said: "the keys of word are given to me." It is understood that Allah makes the word easy to speak very fluently, gracefully and clearly for Muhammad. Furthermore, he is able to express very profoundly the sentences, which nobody can states, and also words of wisdom. It could be inferred from this explanation that Muhammad, whose miracle is Qur'an, open hearts to the happiness and righteousness with the power of word.

The concept of fath and its revivable bas is is one of the greatest gifts given by Islam to humankind. The cities, which have to be symbols of civilization, could be seized by the sword. What if the goal of this power is not to gain in confidence of the hearts and minds of people, whom have been building the meaning of being a city as well as the experiments stemmed from the historical heritage of mankind, it never be eternal and by the same token destined to be lost within the history. Thus, the history is the greatest witness of the fates of that kind of powers. Contrary to these powers, the idea of fath is the name of a deep rooted thought: it is not based on only power, but rather makes people free from the chains and the darkness of chronic dead ends infected to aforementioned experiments, and conveys them to the righteous path and the enlightenment. So, Islam with the concept of fath is the desirous and universal system to reveal the very essence and nature of hearts and minds of human beings positively. The history would firstly be witnessed to the most significant example of this intrinsic reality is the conquest of Makkah (fath al Makkah) by Muhammad who is the model role for all Muslims. This example laid the foundations of a radiant civilization, which inspired humanity with co-existence peacefully throughout fourteen centuries. Consequently, "fath al Makkah is accepted as the beginning of Muslim conquests."

Unfortunately today, there is a popular perception of the apologist and polemical tradition that the claim of universality of Islam, especially in terms of its historical roots is against the assertions of universality of Christianity. ${ }^{8}$ Some confusions about explaining the meaning of the concepts of Islam have occurred because of a lack of authentic Islamic sources for Western Christianity in order to learn them accurately throughout the history. ${ }^{9}$ As a result, "Islamophobia"10 has arised as a contemporary appearing of that aforementioned thinking. The concepts peculiar to Islam such as "monotheism polytheism", "entering the right way (hidayat) - going astray (dalalet)", "putting oneself in Allah's hand (tawakkul) steadfastness" and "justice - persecution" are falsified because of misinterpretation of them. One of those most significant concepts is the concept of fath. It has become distinguished because of that is mentioned in many verses of Qur'an. This paper is trying to explain that fath has an enlivening background to the contrary with the aforesaid perception, in the light of the example of the conquest of Makkah. Pointing out that if a concept is misperceived, it causes a various wrong approaches. As a consequence of them, the originality of the message of Islam is not being reflected in minds and hearts of its interlocutors. Therefore, the most rightful understanding of Islam is only possible through an accurate perception of the basic concepts mentioned in Qur'an.

\section{The Aim of Islam and Fath Al Makkah}

The most important aims of Islam are to establish an environment that allows people to live freely and safely without any doubt and fear, and to open widely the thinking way for minds in order to find the righteous path on the bas is of that environment. ${ }^{11}$ For example, the understanding of Al-Baqarah $2 / 193$ as in mind of earlier of this verse ${ }^{12}$ in this context and reading it with Al-Baqarah $2 / 256$ is the right point: "And fight them until tumult and persecution are no more, and religion is for Allah. But if they desist, then let there be no hostility except against the evil-doers." Therefore, Allah gives people, which open their hearts to Islam freely, priority and appreciates them greatly. But otherwise making somebody believed in something is unfamiliar with the nature of Islam. Furthemore, tyranny, oppression and suppression over minds are understood as an enemy demolishes the essential meaning of humanity. Islam only allows fight to protect human rights and religious freedom against threats. ${ }^{13}$

\footnotetext{
1 See Ibn Mandhur, n.d. : 536

2 See al-Fay ruzabadi, 1986: 297-298

3 See al-Zabidi, 1970: 5

${ }^{4}$ See Ibn Mandhur, n.d. : 537; al-Zabidi, 1970: 5; al-Yassu'i \& Tottel, 2003: 567

5 See Ibn Mandhur, n.d. : 539

6 See Ibn Mandhur, n.d. : 539

7 KIIıç, 2000: 132

8 See Olgun, 2008: 34 etc.

9 See Olgun, 2008: 33

10 See Olgun, 2008: 32

11 See, e.g. Al-Baqarah 2/256. On this point see for an evaluation Kılliç, 2000: 22

12 See Al-Baqarah 2/190-192. See also Al-Haj 22/39-40; An-Nisa' 4/75

13 Kilı̧, 2000: 27
} 
In the light of these ideas it could be said that: religion focuses on the individual. He is the person addressed. ${ }^{14}$ He is perfected. Then he makes the society perfected. As stated in the meaning of benefaction (ihsan) is one of the most significant concepts of Islam that the individual is perfected by Islam is desirous person to be the best in every field of life. ${ }^{15}$ On the contrary to the modern individuality, it is not based on egoistic conception, regardless of the other and allowable personality to do everything even if it is wrong. Consequently, a Muslim as shares his moral, financial etc. gatherings with his brethren, moreover with other people in order that all of them will be perfected as makes himself perfected. Thence, he has to be role model for people in terms of making self-perfected. The best example of that kind of character is the Messenger of Allah Muhammad. His life based on Islamic intellect is dedicated to sustain humankind on the righteous path. At this point, it is enough to mention that fact so as to understand his greatness: he was called " $A l-$ Amin" for his reliability by idolaters themselves. ${ }^{16}$ If your enemies call you "a trustworthy man", there is no gate but you open it.

There are four milestones in the life of Muhammad, which is the best model role for all Muslims. Firstly, the revelation of the Holy Qur'an to Muhammad began in the year $610 .{ }^{17}$ Secondly, for the sake of his values, he was forced to migrate with his followers to Yathrib (Medina). ${ }^{18}$ Thirdly, he had signed Al-Hudaibiya Treaty that played a basically significant role in the seal fate of Muslims in their favour. ${ }^{19}$ This treaty gave a new aspect to the stream of history and opened a new horizon for the exploring Islam.20 Thus it would be the beginning of spread of Islam so quickly. Finally, he conquered Makkah in the year 630. This conquest is the greatest and glorious example of giving importance to the dignity of humankind forever. ${ }^{21}$

With the spirit given by Islam, the basic aim of Muhammad was to rescue Ka'ba Al-Muazzama, the symbol of monotheism from desecrator idols and idolaters. ${ }^{22}$ For this purpose, the preferred way to conquest is rescue the Holy Land without shed blood. ${ }^{23}$ The unaware folly of pagans of Quraysh triggered off the conquest of Makkah. As a matter of fact, Quraysh failed to observe Al-Hudaibiya Treaty ${ }^{24}$ and helped to its alliance Banu Bakr that attacked the alliance of Muslims the tribe of Khuzaa'ah. ${ }^{25}$ Whereupon, the process of the conquest of Makkah begun. Afterwards, Quraysh sent Abu Sufyaan to Medina so as to enable reconciliation and prolong the treaty by regretting the breaking it. But they were not able to maintain the treaty. ${ }^{26}$

Muhammad had very secretly maintained the process of the conquest of Makkah according to the aforementioned aim. ${ }^{27}$ He assembled the amy and seized the ways towards Makkah in order to prevent leaking of any news to Quraysh. ${ }^{28}$ The most of Muhammad's close friends had not been informed about the plans of the operation before it began to be launched. When the amy set out for Makkah on 10 of Ramadan, ${ }^{29}$ Muhammad did not get into the state of Ihram in Thu'l-Hulayfah, the miqat place near to Medina. Meanwhile the Muslim Army deployed in Marr-uz-Zahran, the last muhajirin (refugee) Abbas received Muhammad, ${ }^{30}$ sent his family to Medina ${ }^{31}$ and provided Muslims with secret information related to the polytheists of Makkah through period of the conquest. Furthermore, the leader of polytheists Abu Sufyaan's hope of defence detracted because of the greatness of the Muslim army was showed to him. ${ }^{32}$ Therefore, breaking the resistance of Abu Sufyaan meant that whole Makkah did not fight against Muslims. ${ }^{33}$

Muhammad arranged his army in four groups and nominated his some close friends for each group. It has to be mentioned that one of these commanders Sa'd b. Ubade, who was the leader of Ansar, was discharged from his duty because of his saying that "this day is the right day for us to fight in Kaba". Consequently, another Muhammad's close

14 See, e.g. Al-'An`am 6/94

15 See, e.g. An-Nisa' 4/125

16 See Ibn Hisham, 1992: I, 130-133; Ibn Ishaq, 1981: 57 etc.; at-Tabari, 1987: I, 526

17 See Ibn Hisham, 1992: I, 163 etc.; Ibn Ishaq, 1981: 88; at-Tabari, 1987: I, 531 etc.; Ibn Kathir, 1992: 96; Yörükan, 2006: 49

18 See Ibn Hisham, 1992: I, 335 etc.; Ibn Ishaq, 1981: 154; at-Tabari, 1987: I, 568 etc.;lbn Kathir, 1992: 114 etc.

19 See Ibn Hisham, 1992: II, 776 etc.; at-Tabari, 1987: II, 123 etc.; Ibn Kathir, 1992: 184-188; el-Cabiri, 2001: 151

20 Yörükan, 2006: 196

21 See Ibn Hisham, 1992: II, 842 etc.; at-Tabari, 1987: II, 152 etc.; Kılıç, 2000: 131-140

22 See Ibn Kathir, 1992: 195 etc.; Yörükan, 2006: 263

23 See Sar ıçam, 2004: 207

24 See Keskioğlu, 2009: 122-123

25 See Ibn Hisham, 1992: II, 832-836; at-Tabari, 1987: II, 152-153; Ibn Kathir, 1992: 195-196

26 See Ibn Hisham, 1992: II, 838-839; at-Tabari, 1987: II, 154-155; Ibn Kathir, 1992: 196-197; el-Cabiri, 2001: 152; Keskioğlu, 2009: 123; Sarıçam, 2004: 206

27 See Ibn Hisham, 1992: II, 839 etc.; at-Tabari, 1987: II, 156 etc.; Ibn Kathir, 1992: 197; Hamidullah, 1981: 167 etc.; Keskioğlu, 2009 :

123; Kılıç, 2000: 51 vd.

28 See Ibn Hisham, 1992: II, 850-851; at-Tabari, 1987: II, 155; Sar ıçam, 2004: 207

29 See Ibn Hisham, 1992: II, 851; at-Tabari, 1987: II, 156; Ibn Kathir, 1992: 198

30 See Ibn Hisham, 1992: II, 851; at-Tabari, 1987: II, 156; Keskioğlu, 2009: 123-124

31 See Ibn Kathir, 1992: 198

32 See Ibn Hisham, 1992: II, 853-855; at-Tabari, 1987: II, 157; Ibn Kathir, 1992: 198-201; Keskioğlu, 2009: 124

33 See Kılıç, 2000: 68-71 
friend was nominated in lieu of him. ${ }^{34}$ The Muslim amy entered Makkah from different four routes without blood being shed except for Khalid b. Walid's column. ${ }^{35}$ Some fighters of Qureysh attacked Muslim warriors in his column but they were paralys ed immediately. Even this small attack was enough to sadden the heart of the Messenger of Allah. ${ }^{36}$

When Muhammad entered Makkah on 20 of Ramadan ${ }^{37}$ he ordered that people who took refuge in Ka'ba, their homes and Abu Sufyaan's house would be safe ${ }^{38}$ and wounded people, deserters and prisoners would not be killed. Firstly in Makkah, he made idols and icons around and inside Ka'ba toppled and broken, ${ }^{39}$ circumambulated Ka'ba, prayed inside Ka'ba, requested Bilal to recite the azan over there ${ }^{40}$ and gave a speech to waiting people of Makkah with a great fear following dhuhr prayer. ${ }^{41}$

Muhammad asked them in his unforgettable conquest speech: "What do you think? What behaviour do you expect?" They replied: "We expect forgiveness from you as you are kindest and most noble brother and son of that kind of brother." Hereupon, the Messenger of Allah's mercy said the same sentence which his brother Joseph said it to his disloyal and repentant brothers: "No reproach, this day, shall be on you. Allah forgives you. And he is the most merciful of those who show mercy." ${ }^{, 2}$ This word is very meaningful because of that he did not only conquer Makkah but also the hearts. ${ }^{43}$

In his speech Muhammad highlighted monotheism, abolished every old practice and tradition except the custody of the keys of Ka'ba (sidane) and providing drinking water to the pilgrims (sikaye), made a clarification about the issues of blood money and inheritance, proclaimed that all persons are equal but the criterion of superiority is piety (taqwa) and finally emphasized the importance of Islamic brotherhood. A4 Ansar supposed that Muhammad reunited with Makkah and he never returned to Medina their homeland. When Muhammad perceived their feelings said to them wholeheartedly: "Your life is my life and your death is my death" and emphasized his retum with all of them to Medina. ${ }^{45}$

Furthermore, it is meaningful that Muhammad charged Othman b. Talha with caring the custodian of the keys of Ka'ba (sidane), even if he was not a Muslim, in accordance with "the principle of retuming the things entrusted to the people to the rightful owners." ${ }^{46}$ Then, Othman converted to Islam because of the influence of this Muhammad's behaviour on him. ${ }^{47}$ This is another best example of "fath" gains in confidence of the hearts.

Subsequently, Muhammad took the oath of allegiance of people of Makkah and proclaimed general amnesty. ${ }^{48}$ Nevertheless, fourteen or seventeen people were excepted from this amnesty because of their being guilty of murder or other offences or sparking off the war against the Messenger of Allah and Muslims. ${ }^{49}$ For example, Abdullah b. Sa'd b. Abi Sarh embraced Islam, migrated to Medina, worked as a scribe for Muhammad, but became apostate later, escaped to Makkah and spread propaganda that Muhammad falsified the revelation. ${ }^{50}$ However, they were not all killed except for six of them. The others were forgiven when they regretted and became Muslims. ${ }^{51}$

It is another important point that Makkah was never looted as booty. Muhammad borrowed only some money from some rich people of Makkah so as to give his needy companions ${ }^{52}$ and later he refunded them this money from the booty taken from Hawazin ${ }^{53}$

\section{Conclusion}

Generally, the main aim of the battles of Muhammad is only that the enemies have to be politically forced to be obedient and their false thinking and reasoning should be corrected. It is definitely not slaughtering and destroying them. Muhammad preferred to do psychological warfare instead of shedding blood. He knew to be merciful and kind in the right

34 See Ibn Hisham, 1992: II, 857 etc.; at-Tabari, 1987: II, 158-159; Ibn Kathir, 1992: 201; Sar ıçam, 2004: 211

35 See Keskioğlu, 2009: 125

36 See Ibn Hisham, 1992: II, 858-589; at-Tabari, 1987: II, 159-160; Ibn Kathir, 1992: 201; Yörükan, 2006: 269

37 See at-Tabari, 1987: II, 165; Ibn Kathir, 1992: 202

38 Seelbn Hisham, 1992: II, 854-856; at-Tabari, 1987: II, 158; Ibn Kathir, 1992: 200

39 See at-Tabari, 1987: II, 163 etc.

40 See Ibn Hisham, 1992: II, 861-863; Ibn Kathir, 1992: 202

41 See at-Tabari, 1987: II, 161; Ibn Kathir, 1992: 203

42 Yusuf $12 / 92$

43 See Hamidullah, 1981: 172

44 See Ibn Hisham, 1992: II, 862-865; at-Tabari, 1987: II, 161

45 See Ibn Hisham, 1992: II, 865

46 See An-Nisa' 4/58

47 See Ibn Hisham, 1992: II, 862; Ibn Kathir, 1992: 202

48 See Keskioğlu, 2009: 126-127

49 See Ibn Hisham, 1992: II, 859; at-Tabari, 1987: II, 160-161; Ibn Kathir, 1992: 201-202

50 See Sar ıçam, 2004: 212

51 See further K॥lı̧, 2000: 108-129

52 See el-Cabiri, 2001: 153

53 See Sar ıçam, 2004: 213 
place and time and did everything according to the principle mentioned in the verse Fussilat $41 / 34{ }^{54}$ When taken a look at his battles, it can be seen that there was fighting in his 9 of 27 battles and in these battles, the established total number of casualties only just was 354 including both of Muslim martyrs and the deaths of the armies of the enemies. ${ }^{55}$ Contrary to this reality, when we consider today's devastating wars and catastrophes and their horrible results, we can realize that aforementioned number gives a humanitarian lesson to us beyond ages.

In the light of these data, it could be drawn conclusion that ingenious and strategic initiatives in the process of preparation, realization and finalization of the conquest of Makkah had given great importance to human dignity. Furthermore, these initiatives were patient endeavours that purified the Mother of Cities (Makkah) from pagan footprints defiled its essence and humiliated humankind. Therefore, all these implementations are the best examples of that the life-giving basis of a new civilisation is deep rooted in the great Islamic revolution inaugurated by Muhammad. ${ }^{56}$

Consequently, today's Muslims have to reread and recognise and interpret this most significant and leading experience of Islamic history again. As a matter of fact the modern but experienced orientalism ${ }^{57}$ by many centuries is struggling to cultivate this life-giving system, that is to say Islam, and its followers as in the very negative and destructive images based on Islamophobia in the global public opinion. Therefore, the necessity of that tried to be expounded; a necessity would be the base of counter answer improved by Islamic thought.

\section{Bibliography}

1. al-Fayruzabadi, M. a.-D. (1986). Al Qamus al Muhit. Beirut: Muassasa Risala.

2. al-Yassu'i, L. M., \& Tottel, B. (2003). Al-Munjid fi al-Lughah wa al-A'lam. Beirut: Dar el-Machreg.

3. al-Zabidi, M. M. (1970). Taj al-'Arus min Jawahir al-Qamus (Vol. 7). (A.-S. Harun, Ed.) Beirut: Dar at-Turath al'Arabi.

4. at-Tabari, A. (1987). Tarikh al-Tabari Tarikh al-Umam wa-al-Muluk. Beinut: Dar al Kotob al Ilmiyah.

5. el-Cabiri, M. Â. (2001). Arap-Islam Siyasi Aklı. (V. Akyüz, Trans.) İstanbul: Kitabevi.

6. Hamidullah, M. (1981). Hz. Peygamber'in Savaşları ve Savaş Meydanları. (S. Tuğ, Trans.) İstanbul: Yağmur Yayınevi.

7. Ibn Hisham, A. M.-M. (1992). Sirat-an-Nabawiya (Vols. 1-2). (S. Zakar, Ed.) Beirut: Dar al Fikr.

8. Ibn Ishaq, M. (1981). Sirat Ibn Ishaq. (M. Hamidullah, Ed.) Konya: al Waqf al Khadamat al Khayriyyah.

9. Ibn Kathir, A. a.-F. (1992). al-Fusul fi Sirat al-Rasul. (M. al-Khatraw, Ed.) Dar Ibn Kathir.

10. Ibn Mandhur, A. a. n.d. Lisan al-Arab (Vol. 2). Beirut : Dar Sader .

11. Keskioğlu, O. (2009). Siyer-i Nebi. Ankara: Diyanet İşleri Başkanlığı Yayınları.

12. Kııç, Ü. (2000). Psikolojik Taktik Ölümsüz Zafer Mekke'nin Fethi. İstanbul: Kayıhan Yayınları.

13. Olgun, H. (2008). Tarihsel Bir Kurgu Ürünü Olarak İslamofobya. Diyanet IIlmi Dergi, 44(3), 31-49.

14. Said, E. (1998). Oryantalizm. (N. Uzel, Trans.) Istanbul: İrfan Yayınevi.

15. Sarıçam, İ. (2004). Hz. Muhammed ve Evrensel Mesajı. Ankara: Diyanet İşleri Başkanlığı Yayınları.

16. Uzunoğlu, N. (2010). The Holy Qur'an, Translation and Commentaries . Islamic Publication for the Holy Qur'an Association .

17. Yörükan, Y. Z. (2006). Hz. Muhammed'in Doğumundan Ölümüne Kadarİslam Dini Tarihi. İstanbul: Ötüken.

54 Hamidullah, 1981: 258. The verse from Fussilat, 41/34: "Good and evil deeds are not equal. Repel evil with what is better; you will see that he with whom you had en mity has become your dearest friend."

55 See Hamidullah, 1981: 21. On this point see for an evaluation Kılıç, 2000: 32

${ }^{56}$ See Yörükan, 2006: 264-265

${ }^{57}$ See further Said, 1998. 